\title{
The role of the Teachers in the integration of ICT in Teaching in Secondary Low Education
}

\author{
Prof.Asoc.Dr.Kastriot Buza \\ University of Prishtina "Hasan Prishtina" \\ MA Freskina Mula \\ University of Gjakova "Fehmi Agani"
}

\begin{abstract}
Given the fact that the population in Kosovo consists mainly of young age, youth (15-24 years of age) who include $55.3 \%$ of the population involved in the educational process, then these data can imagine the use of new technologies by young people and it is imperative demand of ICT installation in schools. These changes, the transition from traditional to contemporary learning and learning using the technology undoubtedly will help students and enables them to interact theoretical knowledge with practical ones in order to comply more easily the acquired knowledge. With the integration of ICT in teaching has brought innovation and its challenges on how will be accepted by the teachers but a challenge has been its acceptance by students. The role of teachers has often been hesitant during its integration into teaching. In the theoretical part of this paper are described the problems encountered during the integration of ICT in teaching. Resistance inclusion of ICT by teachers in teaching has been the fear that one day they will be replaced by ICT and will not have the role that they have now. The hypothesis outlined in this paper is: "The role of teachers in the integration of ICT in the learning process enhances the quality of learning"
\end{abstract}

Keywords: Teaching, Information and Communication Technology, students, learning.

\section{Introduction}

\section{Integration and the use of the Technology in teaching}

Increasing the quality of student learning is the main goal of the learning process, therefore, it become the integration and use of technology in schools and especially in the educational process, to have good results. Due to their learning most successful, conditions should be created for this process to be easy for them. Also, to keep pace with their learning capabilities. So the whole process of technology integration in teaching is that the students to have easy access to the information.

\section{Fear of replacing teachers by ICT}

With the introduction of ICT in the classroom, the teacher's role in the learning process becomes more and more critical. What needs to be changed is the role that the teacher plays during these clases. On the other hand, the role of the students it is expanded, the community can also play a new role in the classroom. Information and Communication Technology tools are defined as a "group of various technological tools and resources used to communicate, create, distribute, store, and manage information"(Blurton, 2002).

However, many teachers are not ready to use ICT especially computers and the Internet. There are identified some of the reasons for this reluctance: "poor program design, skepticism about the effect of computers on improving learning 
outcomes, lack of administrative support, increasing the time and effort required to learn the technology and how to use it, fear of losing authority in the classroom (Kiunga, 2008). These are all issues that should be addressed from teachers to fully exploit the potential of computers and the Internet as educational tools.

Professional development of teachers should be long-term, executives, and flexible as far as possible. For many teachers under-qualified, overworked and unpaid, effective adoption of ICT depends on the possibility of giving and continuity to learn what they need to learn, based on their specific circumstances and experiences when they time to learn it. Institutional Incentives and support for teachers to develop professionally is also critical. This can take the form of promotion for teachers who renew ICT in class (compared to only use), or simply making sure that teachers have adequate access to technology after training.

\section{Language and content}

English is the dominant language of the Internet. "It is estimated that $80 \%$ of Internet content is in English language" (Anzalone, 2001). A large part of educational programs produced in the world market are in English. For developing countries where mastery of English is not high, especially outside metropolitan areas, this presents a serious obstacle to increasing educational benefits.

Even in countries where English is the second official language it is imperative that the materials that comprise the national curriculum requirements at the local level for teaching and learning take place and have meaningful content, preferably in the local language. This will ensure that network to be a truly multicultural space and that people of different cultures have a common interest and voice in the global community of learning and practice online.

Particularly damaging to this exemption are isolated, rural populations, cultural minorities and women in general. Thus, attention should be paid to their specific needs.

\section{The teacher as a factor}

The teacher is responsible for creating the environment in the class. He prepares the learning opportunities that help students use the lessons of communication technology. Consequently, it is crucial that all teachers be prepared to provide their students with these opportunities.

Professional development of teachers should have five focus: 1) the ability with special applications, 2) Integration into existing curricula, 3) changing the curricula related to the use of IT (including changes in curricula), 4) Changing the role of teachers, and 5) support the educational theories. (MacDougall \& Squires 1997).

All professional development programs for teachers currently and programs for preparing future teachers should provide rich experiences of ICT in all aspects. Today's teachers must be prepared to use technology to communicate to students, what advantages it brings and know how technology supports teaching process.

Schools today require good ICT skills of teachers to effectively achieve educational content.

\section{Professional development of teachers to use ICT}

In many countries the development and integration of technology in education have also starteted the needed steps to prepare the teachers practicing this technology in teaching and learning process.

The Government of the Republic of Kosovo, namely the Ministry of European Integration through the action plan EPAP 89/2 positions ECDL certification as standard for all civil servants.

This program in Kosovo began in December 2009, including teachers of secondary education from all regions of Kosovo. Generally, about $60 \%$ of teachers are trained in ECDL are equipped with ECDL certificates. Unlike the percentage of active 
teachers certified ECDL is an average $70 \%$. Since the beginning of the project until the beginning of June 2011 they are certified 6.102 people and 2,787 graduated teachers.

From our research with 50 teachers it shows that $41(82 \%)$ of teachers have completed at least one course of ECDL module's. The remaining nine (18\%) of teachers have not carried any module, and it mostly occurs because of their old age.

\section{Research Method and samples}

The survey was conducted with 50 teachers and 325 students of five schools of lower secondary education from classes VI to IX of Gjakova municipality, Republic of Kosovo. The involvement of schools is done intentionally, as a representative group of teachers and students is chosen to research by probability sample from all the courses or subjects.

For this study it is used a questionnaire, the entire questionnaire was anonym, which contains (teachers and students) demographic data of the participants themselves, age and gender, and the second part contains questions for research.

\section{Demographic Characteristics}

\section{Demographic characteristics sample of the pupils}

\section{Sex}

\begin{tabular}{|c|c|c|c|c|c|}
\hline & & Frequency & Percent & Valid Percent & $\begin{array}{l}\text { Cumulative } \\
\text { Percent }\end{array}$ \\
\hline \multirow[t]{3}{*}{ Valid } & Male & 152 & 46.8 & 46.8 & 46.8 \\
\hline & Female & 173 & 53.2 & 53.2 & 100.0 \\
\hline & Total & 325 & 100.0 & 100.0 & \\
\hline
\end{tabular}

Age

\begin{tabular}{|ll|l|l|l|l|}
\hline & Frequency & Percent & Valid Percent & $\begin{array}{l}\text { Cumulative } \\
\text { Percent }\end{array}$ \\
\hline 1997 & 2 & .6 & .6 & .6 \\
1998 & 35 & 10.8 & 10.8 & 11.4 \\
1999 & 80 & 24.6 & 24.6 & 36.0 \\
2000 & 72 & 22.2 & 22.2 & 58.2 \\
2001 & 83 & 25.5 & 25.5 & 83.7 \\
2002 & 52 & 16.0 & 16.0 & 99.7 \\
2003 & 1 & .3 & .3 & 100.0 \\
& 325 & 100.0 & 100.0 & \\
\hline
\end{tabular}

The sample survey involving 325 students, $152(46.8 \%)$ male and $173(53.2 \%)$ female. From age 10 to 16 years where the average age of young people has been $\mathrm{M}=13.1$. And the distribution according to age of the students was 10 years 1 $(0.3 \%)$ student, 11 years $52(16.0 \%)$ students, 12 years $83(25.5 \%)$ students, 13 years $72(22.2 \%)$ students, 14 years 80 $(24.6 \%), 15$ years $35(10.8 \%)$ pupils and students 16 years $2(0.6 \%)$. 


\section{Demographic characteristics sample of the teachers}

\section{Sex}

\begin{tabular}{|ll|l|l|l|l|}
\hline & & & & Cumulative \\
& Frequency & Percent & Valid Percent & Percent \\
\hline Valid & Male & 21 & 6.5 & 42.0 & 42.0 \\
& Female & 29 & 8.9 & 58.0 & 100.0 \\
& Total & 50 & 15.4 & 100.0 & \\
\hline
\end{tabular}

Age

\begin{tabular}{|l|l|l|l|l|}
\hline & Frequency & Percent & Valid Percent & $\begin{array}{l}\text { Cumulative } \\
\text { Percent }\end{array}$ \\
\hline Valid & & & & \\
& & & & \\
& 12 & 3.6 & 24 & 24.0 \\
$1950-1960$ & 15 & 4.5 & 30 & 54.0 \\
$1972-1980$ & 10 & 3 & 20 & 74.0 \\
$1981-1990$ & 12 & 3.6 & 24 & 98.0 \\
over 1991 & 1 & .3 & 2.0 & 100.0 \\
Total & 50 & 15.4 & 100.0 & \\
\hline
\end{tabular}

Research sample included 50 teachers, 21 (42\%) men and 29 (58\%) women. From age 21 to 60 years where the average age of teachers has been $M=41.88$. Distribution by age of teachers has been, from $1950-1960$ included $12(24 \%)$ teachers, from 1961 to 1970 included $15(30 \%)$ teachers, 1971-1980 includes $10(10 \%)$ teachers, from 1981 to 1990 are included $12(24 \%)$ teachers while only $1(2 \%)$ teacher was the birthday from 1992.

\section{Analysis of the achieved results}

Of all the questions we outlined to our research, to validate the hypothesis "The role of teachers in the integration of ICT in the learning process enhances the quality of learning" have been considered these questions:

- From which way of teaching students learn more?

- How does it affect the use of technology in teaching to students?

- How the learning process is affected during the use technology?

-What role does technology have in teaching and does technology replace the role of the teachers?

- Effective and systematic use of ICT in teaching?

From which we had the below mentioned results:

- In the question submitted: "From which way of teaching the students learn more?" And giving explanation that represents traditional ways of learning, written explanation and contemporary ways represents the explanation using technological equipment, we have the following results: 


\begin{tabular}{|l|l|l|l|l|}
\hline Students Reporting & Frequency & Percent & Valid Percent & $\begin{array}{l}\text { Cumulative } \\
\text { Percent }\end{array}$ \\
\hline Traditional way & 108 & 33.2 & 33.2 & 33.2 \\
& & & & \\
Contemporary way & 217 & 66.8 & 66.8 & 100.0 \\
Total & 325 & 100.0 & 100.0 & \\
\hline
\end{tabular}

\begin{tabular}{|l|l|l|l|l|}
\hline Teachers Reporting & Frequency & Percent & Valid Percent & $\begin{array}{l}\text { Cumulative } \\
\text { Percent }\end{array}$ \\
\hline Traditional way & 2 & .6 & 4.0 & 4.0 \\
Contemporary way & 48 & 14.8 & 96.0 & 100.0 \\
Total & 50 & 15.4 & 100.0 & \\
\hline
\end{tabular}

The total number of students participating in the survey, of 325 students, $108(33.2 \%)$ of them have said that the traditional way of teaching is most appropriate for them. Also in this question that 50 teachers involved in the survey, only 2 (4\%) of them have concluded that the most appropriate is the traditional way by which students learn more. The highest number of 217 students (66.8\%) of them said that they learn more from the modern ways of teaching. As well as teachers of $48(96 \%)$ of them have expressed that students learn more by modern ways of teaching. Based on the results of the above query result that the students as well as teachers prefer the same way students learn.

- In the question: How it affect the use of technology in teaching to students? "Observe the following results:

\begin{tabular}{|l|l|l|l|l|}
\hline Students Reporting & Frequency & Percent & ValidPercent & $\begin{array}{l}\text { CumulativePe } \\
\text { rcent }\end{array}$ \\
\hline the class seems more attractive and interesting & 307 & 94.5 & 94.5 & 94.5 \\
Not notice any difference & 18 & 5.5 & 5.5 & 100.0 \\
Total & 325 & 100.0 & 100.0 & \\
\hline
\end{tabular}

From 325 students, 307 of them (94.5\%) said that the time was more attractive and interesting when teachers use technology. While only $18(5.5 \%)$ of them said they did not notice any difference when teachers use technology. From this it can show that students feel more attractive and interesting time when their teachers use technology.

- In the question "How it affect the learning proces the use technology during the class", we note:

\begin{tabular}{|c|c|c|c|c|}
\hline Teachers Reporting & Frequency & Percent & ValidPercent & $\begin{array}{l}\text { CumulativePerc } \\
\text { ent }\end{array}$ \\
\hline Effective & 32 & 9.8 & 64.0 & 64.0 \\
\hline Suitable & 12 & 3.7 & 24.0 & 88.0 \\
\hline Effective and suitable & 6 & 1.8 & 12.0 & 100.0 \\
\hline Total & 50 & 15.4 & 100.0 & \\
\hline
\end{tabular}


$32(64 \%)$ of them reported to be very effective, $12(24 \%)$ reported that it is appropriate, while $6(12 \%)$ of them reported that the hour is effective even when they use appropriate technology. This indicates that teachers perceive the effectiveness of using technology in class.

- At the question: "what role has the technology during the learning and does it substitute the role of the teacher?"

\begin{tabular}{|c|c|c|c|c|}
\hline Teachers Reporting & Frequency & Percent & ValidPercent & $\begin{array}{l}\text { CumulativePerc } \\
\text { ent }\end{array}$ \\
\hline Technology facilitates the work of teachers & 33 & 10.2 & 66.0 & 66.0 \\
\hline Technology prevents the teacher during the teaching & 0 & 0 & 0 & 0 \\
\hline Technology is replacing the work of teachers & 1 & .3 & 2.0 & 68.0 \\
\hline Technology does not replace the role of teachers & 3 & .9 & 6.0 & 74.0 \\
\hline $\begin{array}{l}\text { Technology facilitates and does not replace the role of } \\
\text { teachers }\end{array}$ & 13 & 4.0 & 26.0 & 100.0 \\
\hline Total & 50 & 15.4 & 100.0 & \\
\hline
\end{tabular}

In the given table are reported 50 teachers. $33(66 \%)$ of teachers reported that the technology facilitates the work of teachers. $3(6 \%)$ responded that technology does not replace the role of teachers. $13(26 \%)$ report that the technology not only facilitates the work of teachers but technology cannot replace the role of teachers. Only $1(2 \%)$ reported that technology is replacing the role of teachers. None of the teacher has reported that the technology prevents the teacher during instruction. Therefore the results of this question reject teachers fear that ICT will one day be replacing them in teaching. But only will facilitate their work.

- At the question that how it affect "The effective use of the ICT in the learning process?" the results shows:

\begin{tabular}{|l|l|l|l|l|}
\hline Teachers Reporting & Frequency & Percent & ValidPercent & $\begin{array}{l}\text { CumulativePerc } \\
\text { ent }\end{array}$ \\
\hline Increase the quality of teaching & 46 & 14.2 & 92.0 & 92.0 \\
It affects less on teaching quality & 3 & .9 & 6.0 & 98.0 \\
There is little impact on teaching quality & 1 & .3 & 2.0 & 100.0 \\
Total & 50 & 15.4 & 100.0 & \\
\hline
\end{tabular}

How 50 teachers reported for the efficient and systematic use of ICT. 47 (94\%) of teachers reported that the use of ICT enhances learning outcomes of students. $2(4 \%)$ teachers have reported that effective and systematic use of ICT impact on some results of student learning. $1(2 \%)$ teachers reported that the use of ICT does not affect the results. This shows that teachers are aware that teaching in cooperation with ICT increases student achievement.

All questions for this research prove our hypothesis submitted that the integration of ICT in the learning process by the teacher enhances the quality of teaching and in all this the role of teachers' remains very important.

\section{Conclusion}

Education should adapt to the ongoing changes in technology, and use them extensively in the learning process. To these changes, education must respond, rapidly, internal quantitative and qualitative developments to transmit knowledge and skills systematic, coherent and stable to students by reflecting after these societies to create a future positive for everyone. In the era of information and communication technology development, the use of this technology in teaching and learning has become a necessity for teachers.

In summary the two groups, the students and teachers, based on the ways that are most appropriate for students to learn more, there are no escort a significant difference. We report that $66 \%$ of students have found that their contemporary 
teaching approach is most appropriate for them, even to the same reporting are the teachers, teachers have reported that $96 \%$ of them think that contemporary teaching is appropriate for students.

The analysis results highlight the importance of integration and use of ICT in the teaching-learning process. In analyzing it has been observed that $49 \%$ of teachers although only in a particular lesson, they use ICT in teaching and only $8 \%$ of them reported that they do not use ICT at all during the teaching process. In addition, teachers have reported that they use all the equipment, starting from Radio to a combination of both technological equipment.

Results of the study on how teachers perceive the use of technology, teachers have found that the class is effective and appropriate for students in the use of technology. In addition, teachers have found that the use of ICT in teaching and increase the quality of teaching, as well as also concluded that the technology does not replace the role of teachers, but only facilitate its work.

In general, this study ICT integration requires new types of skills, abilities and attitudes. The general literature shows that successful integration of ICT depends on many factors.

\section{Reccomendations}

To be confronted with changes that challenge today community and educational institution, especially with the integration of ICT, it is necessary to draw up policies and strategies with long-term educational goals. There are three general aims of education presented by the Council for Education, development of the individual, the development of society and economic development, ensuring workforce habit, and developing long-term strategies for ICT integration.

Therefore from the study we are coming at the recommendations for the teachers:

- National policies, policies and actions that need to be taken and coordinated with schools among themselves to have a profound positive impact. There should be a joint plan of ICT integration, support and training for all participants involved in the integration process. Care should be taken to coordinate the attitudes and beliefs of all stakeholders.

- Advise all those involved in the creation of appropriate teaching conditions of educational institutions: Ministry of Education, Science and Technology of the Republic of Kosovo, Municipal Directorate of Education in Gjakova, schools, teachers and other members of the community contributors - that they have important responsibilities to promote the fundamental right of the child to quality education.

- You need to be trained to cope more easily with change, uncertainty, innovation that brings the complexity of technology integration.

- To use ICT to organize regular shape during teaching and not use it as a complementary activity.

- To ensure that all students are able to benefit from the use of appropriate means of ICT in all subjects.

\section{References}

[1] Anzalone, S. (2001). ICTs to Support Learning in Classrooms in SEAMEO. Bangkok.

[2] Blurton, C. (2009). New Directions of ICT-Use in Education". Retrieved from on 7 August 2002.

[3] ECDL Foundation - ICDL - International Computer Driving Licence. Retrieved from on 10 May 2014 from http://www.ecdl-kosova.org/web/

[4] Fluck, A. (2003). Integration or Transformation? A cross-national study of information and communication technology in school education, University of Tasmania, Tasmania,

[5] Goodwyn, A. (2000). English in the Digital Age: Information and Communications Technology and the Teaching of English. Cassell, London

[6] Institut of curricul and standarts, 2005. Programi i Edukimit Teknologjik, Tiranë,

[7] Kent, N. \& Facer, K. (2004). Different words? A comparison of young people's home and school ICT use. Journal of Computer Assisted Learning

[8] Kiunga, I. P. (2008). Integration of ICT in teaching and learning of physics in sekondar school, Kenya 
[9] MacDougall, A., \& Squires, D. (1997). "A framework for reviewing teacher professional development programmers in information technology".

[10] Matthews, B. \& Ross, L. (2010). Research Method. A practical guide for the social science, England.

[11] The Union of Education, Science and Culture SBASHK, (2014). Retrieved from on 20 May 2012 from http://www.sbashk-rks.org/ 